\title{
HIV-I specifically encapsidates other nucleic acids than its genomic RNA
}

\author{
Ludovic Didierlaurent*1, Laurent Houzet ${ }^{1,2}$, Jean-Christophe Paillart ${ }^{3}$, \\ Zakia Morichaud ${ }^{1}$, Fatima Smagulova ${ }^{1}$, Stephan Maurel ${ }^{1}$, Roland Marquet ${ }^{3}$ \\ and Marylène Mougel ${ }^{1}$
}

Address: ${ }^{1}$ CNRS UMR 5236-UMI/UMII CPBS - Equipe "Assemblage et Réplication des Rétrovirus », Montpellier, France, ${ }^{2}$ Molecular Virology Section, Laboratory of Molecular Microbiology National Institute of Allergy and Infectious Diseases, National Institutes of Health, Bethesda, Maryland 20892, USA and ${ }^{3}$ Architecture et Réactivité de l'ARN, UPR9002, CNRS, ULP, Strasbourg, France

* Corresponding author

from Frontiers of Retrovirology: Complex retroviruses, retroelements and their hosts Montpellier, France. 2I-23 September 2009

Published: 24 September 2009

Retrovirology 2009, 6(Suppl 2):P3 | doi:I0.I |86/I742-4690-6-S2-P3 |

This abstract is available from: http://www.retrovirology.com/content/6/S2/P3 I

(c) 2009 Didierlaurent et al; licensee BioMed Central Ltd.

\section{Background}

HIV particles include two-copies of full-length genomic RNA (gRNA) that is selectively incorporated into the viral particles as a non-covalent dimer. RNA packaging into virus particles is dependent upon specific interaction between gRNA and the nucleocapsid protein (NC) domain of the Gag precursor. Selection of the HIV-1 genomic RNA involves the so-called Psi region located immediately upstream of the gag start codon and folded into three stem-loops important for genome packaging (SL1 to SL3). In particular, SL1 mediates RNA dimerization, presumably a prerequisite for gRNA packaging. SL2 and SL3 both bind HIV-1 NC, while SL3 seems to act as the major signal of encapsidation [1]. Little is know about the mechanism by which Gag selects gRNA for incorporation into the nascent virions. In addition, the selection appears weaker than previously thought, since HIV-1 particles also package cellular and spliced viral RNAs in addition to gRNA [2]. The determinants and mechanisms involved in the encapsidation of such non-genomic RNAs remain undefined.

\section{Results}

In order to unravel the mechanisms conferring RNA packaging specificity, we undertook a detailed quantitative analysis of the RNA content of HIV-1 particles by RTqPCR. We determined the relative packaging efficiencies of all singly- and fully-spliced viral mRNAs and of few distinct host RNA species (7SL, U6, and GAPDH RNAs) relative to that of gRNA [3]. We also evaluated the importance of the different regions of HIV-1 RNA and of the RNA export pathway on the packaging efficiency. Although the spliced viral RNA lacks the SL2-SL3 motifs, they were found selectively packaged into virions. Moreover, the persistence of SL1 signal in spliced RNA sequences did not confer packaging ability to these subgenomic RNAs. We found that packaging of cellular RNAs greatly varied from one species to another. 7SL RNA was packaged in wt HIV1 particles as efficiently as singly- and fully-spliced viral RNAs, whereas packaging of U6 snRNA was less efficient. At the opposite, GADPH mRNA was not detectably encapsidated into virions. Furthermore, our results showed that host and viral RNAs were packaged through independent mechanisms [3].

\section{Conclusion}

Recently, we showed that spliced viral RNAs are present in infectious particles and consequently participate, along with the unspliced gRNA, to some of the early steps of infection such as the reverse transcription step [4]. Similarly, packaging of host RNAs could lead to their reverse transcription in an infected cell. These non-genomic reverse transcripts may recombine with the viral genome 
and integrate together into the host cell genome leading to defective viruses or oncogenes production.

\section{Acknowledgements}

This work was supported by grants from ANRS, SIDACTION and CNRS. LH was supported by RTRS, SM by ACl, and LD by ANRS. We wish to thank Célia Chamontin for technical assistance.

\section{References}

I. D'Souza V, Summers MF: How retroviruses select their genomes. Nat Rev Microbiol 2005, 3:643-655.

2. Muriaux D, Rein A: Encapsidation and transduction of cellular genes by retroviruses. Front Biosci 2003, 8: $135-142$.

3. Houzet L, Smagulova F, Paillart JC, Maurel S, Morichaud Z, Marquet $\mathrm{R}$, Mougel M: HIV controls the selective packaging of genomic, spliced viral, and cellular RNAs into virions through different mechanisms. Nucleic Acids Res 2007, 35:2695-04.

4. Houzet L, Morichaud Z, Mougel M: Fully-spliced HIV-I RNAs are reverse transcribed with similar efficiencies as the genomic RNA in virions and cells, but more efficiently in AZT-treated cells. Retrovirology 2007, 4:30.

Publish with Bio Med Central and every scientist can read your work free of charge

"BioMed Central will be the most significant development for disseminating the results of biomedical research in our lifetime."

Sir Paul Nurse, Cancer Research UK

Your research papers will be:

- available free of charge to the entire biomedical community

- peer reviewed and published immediately upon acceptance

- cited in PubMed and archived on PubMed Central

- yours - you keep the copyright

Submit your manuscript here:

http://www.biomedcentral.com/info/publishing_adv.asp 